\title{
The Fallopian Dilemma: African Bodies, Citizenship and Family Planning
}

\author{
Chiara Gemma Pussetti
}

Received: 28 April 2014 / Revised: 6 July 2014 / Accepted: 11 August 2014 / Published online: 8 October 2014

(C) W. Montague Cobb-NMA Health Institute 2014

\begin{abstract}
In the recent context of the European Union governmental activity - in particular in this time of crisis - immigration-related issues became of pivotal importance. Social healthcare programmes targeting deprived immigrant populations equate reducing social problems with guiding their conduct towards more responsible, healthier habits and life projects. Building upon a set of debates on governing the body and health under advanced liberalism, this paper, focusing on the Portuguese context and on family planning, suggests ideas towards a new research agenda on immigration and public health, claiming that social care interventions are inherently racialized. The insecurities, threats and overall concerns in a time of global crisis create a state of exception, which justifies the deployment of illiberal practices in order to secure collective well-being. In particular, I am interested in how the dominant discourses of the health and social care sectors influence [1] the ways in which "the right thing to do" is constructed and debated and the material effects of these decisions on immigrants lives; [2] the ongoing strategies, micronegotiations of power and truth between different actors; [3] the fading borders of the subject of medical knowledge, which becomes no longer to govern the body merely according to a medical logic, but rather to seek social well-being.
\end{abstract}

Keywords Women health · Family planning $\cdot$ African sexuality $\cdot$ Immigration

\footnotetext{
C. G. Pussetti $(\square)$

UFRN, Natal, RN, Brazil

e-mail: chiaragemma.pussetti@gmail.com

C. G. Pussetti

ICS/UL, Lisbon, Portugal
}

\section{The Story of Liliana: Thinking about Race, Poverty and Reproductive Rights}

Liliana Melo is an immigrant woman from Cape Verde. She is 34 years old and lives illegally in Portugal for 20 years. Since January 2013, she has gained media attention. By decision of the court of Sintra, in June 2012, seven of her ten children were removed and placed in a children's institution, waiting for adoption. The Superior Council of Magistracy (CSM) ensures that the decision of the judges of Sintra is based merely on the existence of objective risk to minors, related to their health and safety. In the court's judgment, as well as in the process, there is no reference to physical or psychological abuse and the judge talks of a cohesive family. The children are loved, have success in school and are well integrated into their social environment. Despite the absence of violence and abuse, and the confirmation of strong family ties, social workers noticed an inability of the mother to provide the necessary care to all the children, with the aggravating circumstance of their father's absence.

The social services technicians list the various problems encountered, including the following: lack of personal and household hygiene; lack of general supervision; minors taking care of other children; teen pregnancy of two daughters; delay in vaccines; and routine paediatric consultations. Mrs. Melo has given birth too many times and too often and the state had to intervene to tell her to take "responsibility" and stop getting pregnant. If she does not follow these recommendations, then the state can intervene with sanctions such as losing their council housing, losing their unemployment and family benefits, or having their children put into care to persuade her.

In 2007, a first promotion and protection agreement was prepared, which provided measures that forced the mother to vaccinate children, take care of their hygiene, accompany them to school, ensure medical appointments, supervise and drive the behaviour of the adolescent daughters in a more convenient direction. In 2009, they added to the agreement 
further measures, such as "The mother will have to provide proof of her attendance at the Hospital Fernando Fonseca, undergoing a surgery process of tubal ligation".

The obligation of tubal ligation by the mother as a concrete measure of minors' protection generated a great public controversy. According to the judgment of the Family and Juvenile Court of Sintra (25/01/2013), the mother was not forced to undergo sterilization against her will, but she has assigned voluntarily the proposed agreement, in order to keep the custody of her children. A report from the Children and Youth Team (ECJ), which advises the court and is under the tutelage of the national social care service, states that "In February 2010, the mother confirmed that she had signed up for tubal ligation in order to maintain her children custody, but the hospital replied that she is lying and there is not any application or registration". In August 2010, another report states that "the progenitor persisted in rejecting the tubal ligation." It is said also that, "contrary to what she had undertaken in the children protection agreement, the mother failed to tubal ligation and since then she has had other four children." The birth of these new children, in social care technicians' opinion, worsened the economic situation and lack of organization of the family.

Despite the commitment, Mrs. Melo never proceeded to tubal ligation, which resulted in a violation of the agreement for the promotion and protection. Given her resistance to the surgery, supported by religious motivations, as she is a Muslim woman, the judge said she had to leave in Africa her habits and traditions, in order to adapt to the Portuguese lifestyle and to have a "normal" family. The nuclear family appears as a powerful normative ideal in the judge's argumentation. Liliana's family does not follow this pattern, so it is considered deviant, socially dysfunctional and structurally disorganized. $^{1}$

By decision of the Court of Sintra, the children were taken away from the family and therefore subject to the more extreme minors' protection measure: given up for adoption and losing all parental bonds forever. The media attention on the case of Liliana produced opposite reactions. On the one hand, raised up the voice of a lot of immigrant African women who report being forced to lacquering their trunks or abort to be able to get grants for their family or to retain the custody of their children. On the other hand, surged a xenophobic eco accusing immigrants of living at the cost of the Portuguese taxpayer "they want to have children and then who is to grow them up? The state? Ask to Allah. Or maybe Allah does not know of your situation? (...)". Liliana tells me that these affronts are very common, when she goes out with their children. The comments of the neighbours are definitely disagreeable, but the most scaring thing is the hospital. "When I got pregnant, I always tried to go to the hospital right at the

\section{${ }^{1}[40] ;[3]$}

end of pregnancy because I'm afraid that they close my tubes without my knowledge. For my last child, I didn't go to the hospital at all, and I've not done any anagraphic registration, fearing that they took my children away" says Liliana.

Dona Binta, a neighbour originally from Guinea Bissau, begins to tell us that she accepted the tubectomy 2 years ago, as a condition to receive family allowances. She talks about her sterilization not as a choice but as an imposition, even though it is a deal that she might or might not accept. Now, she has obtained aids to feed their children and pay the rent, but the price paid was very expensive. "I am only 32 years old, says Binta, but as a woman I'm finished". If we cannot speak of coerced sterilization, for low-income women, the offer of money to feed, clothe and to pay the rent of the house, or the permission to keep their children with them, it could be difficult to refuse. After this controversy, three important Portuguese associations supporting mothers ${ }^{2}$ indicated a list of names of immigrant women pressured to abort by national social care service or, in other cases to sign documents authorizing the tubal sterilization or contraceptive implants, in order to leave the hospital after having the baby.

Liliana exposes the factors that determined the judges' decision with extreme clarity, emphasizing how in her opinion it does not depend on the fact that she has lost her job-a condition common to many Portuguese people in this time of crisis. Neither, it depends on the fact that the house is messy, because with ten children, it is quite normal. Neither on the assessments of social workers, who appeared only four times in 6 years to confirm domestic conditions, but that never gave any kind of support or aid. The real problem is the colour of her poverty. "I'm an African woman, I have a lifestyle very connected to my religion and my traditions, says Liliana. And I live in a slam. We both know that if I were white, nobody would take my children nor asked me to waive my reproductive rights". In her opinion, the right to conceive, bear and raise children applies race and class criteria that distinguish between Portuguese middle class white and married women, which should bear children, whereas single, low-income immigrant black women, which should limit their childbearing. "We are punished for our sexuality and for bearing too many children. We are described as dependent, irresponsible, prone to addictions, and inadequate mothers. So the state tries to discourage childbearing, depriving us of the means to support our children, taking away our children, or encouraging us to accept medical procedure like abortion or sterilization".

The clarity with which Liliana explains the situation and its discriminatory dynamics, is reported by the judge: "Liliana Melo, Cape Verdean, speaks Portuguese properly and defends her reasons with an articulate speech. Discourse that clearly does not belong to her and reveals that has been "built",

\footnotetext{
${ }^{2}$ Missão Mãos Erguidas; Ajuda de Mãe; Associação Portuguesa de Famílias Numerosas.
} 
possibly by someone that is advising her, putting the right words in her mouth". Is Liliana an irresponsible, undisciplined and libertine woman, a parasite, who is defrauding the state and living at the cost of Portuguese people? Is she an uneducated woman, unable to articulate and coherent discourse? Is her fertile, sensual and maternal body a serious threat, which should be limited, locked, corrected?

Analyzing carefully healthcare practices, we can recognize the variables (origin, nationality, social class) that determine which families will be targeted for intervention and which women are most likely to be proposed long-term contraceptive measures, such as tubal sterilizations and subcutaneous contraceptives. African women, in particular, are considered as very "bad or irresponsible mothers" [12] due to cultural factors and characteristics of a supposed "African hipersexuality", which have to be corrected and altered in order to transform them into competent citizens, capable of governing and take care of themselves and their family [36].

\section{Portuguese Ethnopolitics of Citizenship: Empowerment, Emancipation and Self-Government}

My fieldwork started out with an analysis of the discourse of social workers involved in different on-going projects in the Greater Lisbon area. I carried out over fifty semi-structured interviews with health and social assistance technicians, ONG officials, social rehabilitation technicians linked to CLDS (Contrato Social de Desenvolvimento Social), ${ }^{3}$ ISS (Instituições Particulares de Solidariedade Social) ${ }^{4}$ and RIAC (Rendimento Social de Inserção). ${ }^{5}$ I carried out 43 open interviews and wrote the life histories of five users of the above mentioned services; I organized eight focus groups, four of which with social work professionals and four with users of African origin. I was present during several medical appointments and attended responsible parenting and family planning workshops. I analyzed the goals of the main community intervention projects linked to Greater Lisbon's CLDS and carried out semi-structured interviews with representatives of the projects, independent experts from the National Inclusion Action Plan, with technicians from the Office for Religious and Special Social Affairs, the Directorate-general for Social Rehabilitation and the Family Planning Association. I've combined different levels of analysis, in order to offer a wide-ranging and inclusive perspective. I've examined health policies as an ethnographic object itself, observing the cultural assumptions, debates, practices and processes behind welfare reform. To analyze policies means considering not only a group of people or a particular set of

\footnotetext{
${ }^{3}$ Local Social Development Projects.

${ }^{4}$ Private Social Enterprises.

${ }^{5}$ Guaranteed Minimum Income (GMI).
}

documents, but a specific constellation of actors, activities and transnational influences that shape policy-making. An anthropological approach aims to view policy from the eyes of these actors and to uncover the activities and influences that shape policy decisions and their implementation, effects and how they play out in the field. Classical in-depth ethnography provided the central tool of research. In particular, I've used structured and semi-structured interviews with the following: health and social care professionals, governmental and nongovernmental social service employees and immigrant patients. I've also used life stories and focus groups as methodological devices. The main aim of my research was to analyze programmes of health education for migrants as important instruments to further their integration and facilitate their access to health care. Unfortunately, many such programmes show no respect or understanding for migrants' own health beliefs, values and way of life. The results of this research were destined to provide a strong directive for decision making to both healthcare professionals as well as policy makers. There are no precise rules and directives regarding the creation of a transcultural and culturally sensitive therapeutic encounter, but efforts in the continuous pursuit of such goals should be made. Into the framework of the European project "T-SHaRETranscultural Skills for Health and CaRE", a LLPLeonardo da Vinci Multilateral Projects for Development of Innovation Project, which involved nine partners from five European countries (Italy, Portugal, France, Slovenia and Norway), we have therefore decided to propose some guidelines and possible orientations that serve the purpose of achieving a critical, and above all, reflexive approach, capable of considering immigrant patients as political and moral subjects. We highlight the importance of addressing some general effects of unaware socio-sanitary practices, which risk to perform peculiar normative attitude towards minds and bodies, objectifying a specific model of 'person' through the prescription of a specific moral order. T-SHaRE Standards and Guidelines for Practice and Training was the main outcome of this project. This work arises from the evidence that the migrants and ethnic minority members presently do not receive the health care that best responds to their needs $[33,34,37,38]$.

As a point of departure for a reflection on the racialization of social intervention in Portugal, based on an interpretation of the intimate relationship between stereotypes and perceptions regarding cultural others, and assistentialist practices, I present the following excerpts of interviews carried out with key professionals from these organizations: officers (who generally have an academic training in Psychology) and technicians (nurses and social assistants).

"One of the features that most of the African immigrant populations have in common is its physical, psychological, and social vulnerability: the dangerous fragility causing them to become passive and dependent beings. 
Socio-educational intervention seeks to restore these people to society, strengthening their self-sufficiency by means of enablement, leading to their emancipation. Promoting individual and social responsibility implies creating healthy habits and developing work ethics, assets that are essential for these people to achieve their independence. We try to help them acquire self-discipline. We have to teach them how to run their affairs more effectively, how to give a correct and suitable use to their houses, how to care for themselves and their children with dignity".

"In our opinion, these vulnerable individuals don't know how to make use of the options at their disposal, they don't know how to put their lives on the right track, and therefore we lend them a hand, as you would to help a child walk. This is the best definition of vulnerability: people who are poor, lacking in education, initiative, and therefore needing support, just like children. We have to give them direction, provide clear instructions as to the right and wrong choices facing them: we are not yet at the stage where these persons are ready to stand on their own two feet."

In both these excerpts, the underlying, though as yet implicit premise, is that these persons lack the necessary skills to run their own lives. All the technicians I interviewed in the course of the 2-year period of research, claimed, albeit in different words, that immigrants need to be taught how to lead constructive lives: their life is disorganized and lacking in the necessary discipline to make their actions match their intentions. It is the duty of professionals to try to educate and emancipate these persons so that they may acquire the attributes, which characterize good citizens, to become self-sufficient, incorporated in the work market and able to participate in civic life.

The goal of a professional is to transform people who are destitute - not only economically, but also culturally and civically — into individuals capable of adjusting their behaviour to new and more acceptable standards. In other words, governing the margins is not so much a mechanism of social control as a space for fostering citizenship. The struggle against marginalization implies a kind of moral transformation, insofar as it attempts to introduce civic virtues, fostering valuable habits and mind sets as well as appropriate conducts. By adopting this pedagogical attitude, technicians in the assistance sector are encouraged to act as authority figures beyond their role of assistance.

The metaphorical association of the immigrant with a child that needs to be educated, disciplined and led by the hand in the right direction was present in most of the interviews that were conducted. As the children projected by that image, vulnerable people lack the ability to know what is best for them, much less to develop the necessary self-discipline to act effectively upon that knowledge. As the adults in that metaphor, social assistance professionals are in a position to know what is in the minor's best interest and make decisions for them, even without their consent. The challenge is to turn deprived citizens from passive recipients of assistance into active and independent individuals.

To do so, ways are found to reinstate those excluded from the circuits of responsible self-management, to restore them by activating their capacity for autonomous citizenship. That is the chief concern of the Novo Programa de Emergência Social $^{6}$ which was presented on August 5 of 2011 by Pedro Mota Soares, minister of Welfare and Social Security: to fight dependence and promote the enablement of individuals. The minister shows his concerns in light of the present crisis besetting Europe and Portugal in particular, stressing the importance of proposing models of social innovation that can provide solutions to insure that the weakest and the unprotected are not left behind. According to Pedro Mota Soares, "our action must focus on the enablement and personal promotion of those who are in risk of exclusion".

The Social Emergency Program that should remain in force at least until December 2014 rests on three key principles. The first one concerns the fight against dependence and assistentialism:

"We will not spend on bureaucracy, we will invest in people. We don't want welfare to become a permanent form of existence; as the Chinese proverb says, in some cases we will give people the fish, in others we will teach them how to fish".

The second principle has to do with the social resentment that opposes the value of work to the system's fraud:

"Portuguese society wants to grant equal opportunity to all based on the value of work, and make sure that the money collected through taxes is not vulnerable to fraud and abuse".

The third rule emphasizes the debate that surrounds the role of the state in terms of promoting a social network supported by the state as opposed to the privatization of the social assistance sector:

"Such a program doesn't necessarily mean a bigger state, but more social institutions and better social policy. A network of social solidarity should include everyone. We rely on the proximity and experience of social institutions in the field; we cannot encourage the permanence or dependence on welfare (...) because welfare always entails a moral risk: that it remains preferable to lean on the state's help even when conditions for work exist."

\footnotetext{
$\overline{{ }^{6} \text { New Social Emergency Program. }}$
} 
The challenge is to fight against the "situations of long term dependence, which a juncture of social emergency typically bolsters" and reduce "the moral risk of dependence" by investing in the autonomy and enablement of individuals. Indeed, the development of modern welfare regimes has from the very beginning been closely attached with the problem of dependence.

Dependence and poverty are two different things. Being poor is an objective condition; being dependent is also a subjective disposition. Being poor is usually linked with certain valuable personal traits; dependence rarely so. In fact, what might be described as respectability in poverty corresponds precisely to the ability to resist the temptation of dependence. Being a dignified poor means not asking anyone for anything. Dependence is associated with an incomplete way of life: normal in childhood, abnormal in adulthood. The notion of dependence is thus politically interpreted as something distinct from poverty and linked to the helplessness, absence of initiative and good will of certain sectors of the population.

There is obviously nothing original in the idiosyncrasies of the present situation in Portugal regarding these discussions. The trends that have dictated the reconfiguration of social care networks are closely connected to extremely relevant shifts occurred in the last decades, in which the state has played an increasingly complex role and for which the American context emerges inevitably as the most determining vocative internationally. Pedro Mota Soares's new program echoes Bill Clinton's proposal of the Welfare Act, which would become known as "the end of welfare as we know it". Its goal was to eliminate dependence on the assistentialist system, helping people to become self-sufficient, autonomous, responsible and productive members of society.

The myth of the welfare queen, the African American single mother driving a Cadillac, freely cheating the welfare system, thoroughly exploited by Reagan in his famous 1976 presidential campaign, would not only enter American folklore - actually also of the European one - but would equally be turned into a banner in discussions dealing with particularly complex social issues. On the one hand, it described the creation of a class of dependent individuals devoid of dignity or autonomy, who were helpless or unwilling to be selfsufficient and look out for themselves. On the other hand, it equated being a beneficiary of the system with being a person with no moral character, and by extension helped to build the idea of the social support system as a haven for apathy, sloth and moral decadence. In this way, it gave rise to a new interpretation of poverty according to which it is no longer essentially a problem of classist nature due to socioeconomic inequality and uneven distribution of wealth, but as an inherently racial issue tied to behavioural deviance, moral flaw and cultural pathology.
Migrant populations, the cultural others who make up that surplus population putting pressure on the margins of fortress Europe, become the antithesis of the liberal self. These individuals are construed as being vulnerable, but also a risk: they lack the necessary skills to exercise their freedom, but they also lack the moral and psychological traits essential for the exercise of a liberal kind of citizenship, such as self-sufficiency, autonomy and even control over their passions or sexual impulses. We are therefore told that we must act on two levels: one that is structural, in which the goal is to create the right institutions, promote civic society and remove the political and economic obstacles to progress; and one that is pedagogic, in which the goal is to educate, cultivate the skills of the individual, promoting a moral and personal transformation towards an autonomous and liberal self.

The first dimension of our problematization is therefore this obsessive focus on underprivileged populations - and in particular with populations coming from underdeveloped contexts - which persists until today; the mentality that supports the creation of a sphere of intervention over those who are allegedly unable to care for themselves. The second dimension in our problematization is the particularity that this type of post-second world war interventionism on poverty is, from the beginning, inherently racialized, rooted in the shift from a colonial concern with the "biological types of a place" to a contemporary preoccupation with "circulating cultural types", symbolically and politically projected on immigrants, the embodiment of cultural difference in movement (Duffield 2007). Assistentialist policy is thus primarily an ethnopolitics of citizenship. Again, that does not mean that the rationalization of intervention on poverty is racist, but racialized; just as it does not have a neocolonial nature, but instead is literally post-colonial. From what we can observe, what has indeed been perpetuated is the division of human groups according to the absence of moral and cultural features or bio-psychological inclinations that require correction by means of education and guidance, justifying a form of liberal supervision [16, 31] over those populations.

Even though there are different techniques of social intervention which share the goal of guiding excluded populations on the path to a responsible citizenship, here, I decided to address only one of the areas of my research, health, presenting some preliminary data that can be used to exemplify how this method of caring for immigrants by guiding their conduct, is deeply embedded into people's lives. In fact, the field of medical intervention plays a central role in depolitizing governance over life and death, health and sickness, in the attempt to drive people to acquire healthy habits, reduce risks and attain certain normalized conceptions regarding their body, their education, in sum, what may medically be considered a healthy body. Bear in mind that the persons who apply for welfare are advised (often compelled as a condition for 
eligibility) to attend workshops designed to develop their skills and build a life project for themselves. Then I studied more closely some of the courses aimed at teaching positive parenting through specific counselling activities, education and parental training, conceived to promote responsibility, improvement of parental skills and prevent repeated pregnancies.

\section{Indocile Bodies and African Hipersexuality. Homo Ancestralis, Jezebel and the Welfare Queen}

"There are many destructured families and a great lack of parental skills, added to serious problems of domestic, personal, moral hygiene. Especially within African families, you can't imagine: white neighbours are very sensitive to the noise, the confusion, the behaviour ... you know what I mean, right Miss? Immoral conduct, indecencies (...) Changing mentalities is difficult, and we have to force them to come to our classes, otherwise they don't come".

"The so-called white population very rarely takes part in any kind of street party, they don't like to, don't want to. Africans on the other hand love loud music; their behaviour is more extravagant, which ultimately means more drinking, regular stuff, beer, nothing fancy, some wine, they didn't even have much money for anything else, but it's the kind of lifestyle that in the end can lead to perdition. African families are the most unstructured ones, where there are many different problems within the same household: unemployment, alcoholism, welfare dependency, criminality among the older ones; they all sleep together, and children might be exposed to scenes of adult intimacy. The purpose of our intervention is to change this type of behaviour. Maybe that is the African way; maybe it's normal for them. Unfortunately here they have to change, this has to be Portugal, not Africa, there it is, perhaps it is just a matter of the dictatorship of the majority, but that's the way it has to be."

"We have the African immigrants with very strong cultural issues, which means having single-parent families, single mothers with $3,4,5$ children. The thing is that we rarely find father and mother together. These are women who normally do not believe in abortion; they have the children, and are generally good mothers, but should nevertheless have fewer children. We try to explain it to them, but they don't understand the concept of prevention. For the African male, using a condom, when I bring up the subject with the girls, explaining that it is important, that it prevents diseases, they tell me that the men don't accept it, don't want to use it. I also believe that Africans, in terms of sexuality, are a little excitable. A colleague of mine used to say that they might be waiting in a bus station and it only takes a simple brush against their arm, and two minutes later they are already making out; they are a little like that, the physical side, all the sensations on the surface, and that is a trigger. But in Africa children are raised by the community, they just have the children and the community takes care of their upraising. Here in Portugal they continue the same behaviour, raising the children on our welfare system. As they are incapable of understanding prevention, we have to take more drastic measures". "We are talking about very big families, scores of six or seven children managed by a single mother who is herself quite young. Some girls keep returning every nine months to the maternity to deliver a new baby. If truth be told, Africans are very prolific; they don't mind burdening their wives with all these pregnancies. They don't mean any harm, it's in their instinct, you know, they are very focused on the sexual side and don't stop to think of the other things. But we cannot forget that programs such as the "guaranteed minimum income" are also available to immigrants, and that these programs actually reward irresponsible reproduction. It is our duty to counsel and encourage women to undergo tubectomy. With our support and thanks to the work we do, many women have accepted having their tubes tied, and thank goodness for that, otherwise by now they would probably already be in their twelfth or thirteenth baby!"

"Some kind of action is necessary to limit recidivating pregnancies, and to be able to grant a healthier development to the already existing children. It is like the trees, you see; large number of fruits, but mostly small and of poor quality. That is why pruning is so important."

All the technicians who were asked about family planning, contraceptive counselling and sexual and reproductive education pointed out the African populations as especially problematic, due to cultural factors and natural characteristics of the "African personality". Curiously, the ideas connected to the supposed behaviour and mentality of Africans reflect an echo of the past and particularly a type of colonial psychiatry which attempted to give scientific validation to the hypothesis of biological and moral inferiority of subjected populations. Colonial doctors and psychiatrists conjectured on the alleged simplicity of the Negro mind, a manifestation of less evolved cerebral structures. In the psychiatric reports from that period, we find the conviction that the "negro" lacks self awareness, maturity and shows little capacity for individual integration in terms of its sense of responsibility; furthermore that they have the emotional maturity of a child, are dominated by their animal instincts and tied to the immediate present while unconcerned with the future. I have already dealt in other works with the problem of how the legacy of colonial medicine 
determines many of the present stereotypes concerning Africans in clinical contexts ([32], 2009). In a different article [35], I present the current debate surrounding the sexual life of Africans by readdressing the hypotheses proposed in colonial medical reports regarding "negro sexuality". A few years ago the so-called Caldwell polemic caused some anthropologists $[25,1]$ to bitterly contest the theses of a demographer, John C. Caldwell on the allegedly heightened, savage and unregulated "African sexuality" ([10, 6, 7] e [8, 9, 11]). According to this author, in Africa, no moral, emotional or religious value is attached to the sexual act, and therefore, we cannot expect to find any trace of romantic love, or sense of responsibility towards offspring or women in the African continent. In order to support his argument, Caldwell [5] suggests the definition Homo Ancestralis as a different species from Homo Sapiens, to differentiate Africans form Euro-Americans. The statements made by Pope Benedetto XVI during his visit to the Republic of Cameroon in 2009, and the contrasting reactions that they attracted, brought the Caldwell debate once again to the forefront of contemporary concerns, showing that the issue still carries a strong ideological and political sway. This distinction mirrors the Darwin's division from 1871 between the categories of the prudent-better man versus the reckless inferior man, the latter accounting for the majority of the population. Recent studies have shown how sexual education and teenage pregnancy prevention social interventions are highly racialized, thus helping to create an opposition between the image of the immoral, uneducated, poor and sexually available black girl, and the sexuality of white women: middleclass, educated, pure, moral, passive and responsible $[15,20,39,19,27]$. The discourse of professionals replicates the stereotyped image of an impudent and libertine sexuality, of an animal-like fertility.

Within this stereotype, young men are represented as primitive animals, dominated by instincts, unconscious and totally driven by the immediate satisfaction of basic biological urges, and obsessed with the search for pleasure ([41]: 127); as violent, "hypersexual brutes" ([28]: 296), trapped at the bottom of the evolutionary ladder, as John Caldwell's definition of Homo Ancestralis suggests. As David Leonard observes, the black male body ultimately represents everything deviant, criminal and threatening (...) as a symbol of decadence, chaos and danger ([28]: 298). The African male body is viewed as the epitome of savage violence, unlimited physical force and unrestrained eroticism ([26]: 34). But the utter absence of moral responsibility and rationality require control and confinement, to protect the rest of the population from the risks entailed by this threatening and predating black body. As Herman Gray and Sander Gilman emphasize, the black other occupies an ambivalent place in the white imagination, between fear and desire, repressed fantasies and troubled sexuality ([23]: 165; [22]: 23; [4]): something that is fascinating but at the same time warrants the need for surveillance, control and punishment ([2]: $111 ;[13,21,24])$.

Girls, on the other hand, are portrayed as being sexually too provocative, proactive and available, vulgar and much more interested in financial gain than in romantic relationships, thus casting the shadow of prostitution over the image of the African woman. Put in an uncomfortable position between the stereotype of Jezebel-lascivious and immoral prostitute-and the Welfare Queen-calculating, opportunist, cheating and taking advantage of the system - the African woman today is given an image in which love, money, sexuality, colonial imagination and post-colonial policies are woven together to create original configurations that are extremely interesting from the point of view of the anthropology of emotions [14]. The essence of discourses based on the prevention of teenage sexuality and contraception is thus revealed to be extremely racialized. The young African woman is at the same time considered to be very experienced in terms of sexual activity - prematurely provocative and availableand absolutely ignorant in terms of sexual education and prevention.

"So, you can tell that the African community is full of taboos, there is a serious obstacle to dialogue ... in parents talking with their children about sex and explaining to them about prevention, family planning and that sort of thing. And we receive young girls who knew very well how to do stuff, but were completely in the dark regarding matters of sexuality and sexual behaviour (...). We don't want them to turn the generosity of the tax-paying Portuguese citizens into a form of existence, right?"

Social intervention must therefore be at the same time an act of redemption, correction, protection, support, education and accountability. Family planning should on the one hand enable a better organization of domestic life, promote responsible parenting and greater independence for the women; on the other hand, it must reduce the risks of fraud and wrongful use and avoid the trap of welfare dependence.

\section{Implanting Citizenship: Family Cap Policies, Contraception and Sterilization}

In the words of one of the nurses and a social assistant from the family planning counselling unit:

“There are many irresponsible girls: they don't do any family planning, and when they become pregnant, the only method they use is abortion. Then there are others 
who have one baby after another (...) in extreme situations some doctors even suggest doing a Tubectomy, but usually the precaution we take is to insert a subcutaneous contraceptive implant in the arm of girls who come to us with any kind of health issue. It's an easy and efficient form of prevention, considering that many girls don't know how to be disciplined in terms of family planning".

"These women living in situations of social vulnerability are overloaded with their numerous domestic and professional obligations, leaving them very little time to dedicate to their children and thus abandoning them psychologically and developing with them very poor forms of interaction. For these reasons, the preferred measure is the insertion of a subcutaneous hormonal implant, which is a safer method of contraception since it doesn't require so much discipline and attention as the pill, nor agreement from partners to use condoms. When they already have children, especially in the case of African women, we advise tubectomy because it's an easy method, and the problem is solved with minor surgery".

"We already have girls actually turning to contraception, wanting to use contraceptive methods, and I think that is excellent. They ask for the pill, but you know, it is easy to forget taking it, so therefore the best thing is to get a device implanted straight away, so they don't have to resort to a voluntary interruption of pregnancy at age 14 . I'll be honest with you, theoretically, before deciding on a method, the implant for instance, there should be a careful explanation about its advantages and disadvantages, and the women should use that information to do some reflection, in other words, it can't be like "right now? Ok, get it done right away!" But most times it has to be like that, it's the only way".

The role of the health technician or the social assistance professional - mediators between the state and the future citizens - in guiding immigrants in the direction of a western parenting model, is crucial. Legitimated by the authority and objectivity of scientific knowledge, possessing the expertise in health and prevention, professionals enter all those counselling appointments absolutely convinced that they know what is best for the users, much better than they know themselves. This kind of relationship is obvious when we analyze the data obtained from the interviews carried out during fieldwork with women of African origin.

Lúcia (28 years old, Cape Verdean, mother of 3 children):

"The doctor suggested that I tie my tubes because I cannot afford to support more children. The social assistant asked me: are you sure? You are only 28, you may still want to have more children and tubectomy is irreversible. Yes, I know but the doctor says that I don't have the means to raise another child and I'm afraid that I might lose my welfare".

Karen (26 years old, Guinean, mother of 3 children):

"When I had my appointment, the doctor said that the best thing for me to do was to do a tubal ligation. They mentioned that it was the right choice so that I could take better care of my children and be a good mother. I want to be a good mother, even if that means not getting pregnant again. I knew that a cousin of mine and other friends had already done it, and since I already had my children I decided to go ahead with it".

Marlene (34 years old, Cape Verdean, mother of 5 children):

"After my fifth pregnancy the nurses insisted a lot for me tie my tubes so that I wouldn't have any more children, but I didn't want to, and always refused. When I was pregnant the last time, they insisted on doing a Csection. I didn't understand, since my other deliveries had been so easy ... all I know is that since then I never became pregnant again. Do you know if there is any test I can do to make sure that they didn't use it as an excuse to have my tubes tied"?

Eveline (27 year old, Guinean, mother of 4 children):

"I have already had my tubes tied, and yes I was advised not to have any more children, that I already had 4 and that the procedure seems be effective. I don't know for how long, I should expect at least for five years".

Rita (24 year old Cape Verdean, can’t get pregnant):

"I had a cyst removed when I was eighteen. God knows what they did in the hospital. If I could go back I would never let them touch me. I'm scared that they may have closed my tubes. I'm convinced that if I can't have children now it's because of them".

Several studies show that there is a connection between the use of tubal ligation as a contraceptive method and women's origin, the African and Brazilian women being more inclined to use this method than the Portuguese. These studies stress that often, due to problems related with the nonexistence of any kind of cultural and linguistic mediation, and with misunderstandings and misinterpretations in the course of doctorpatient interaction, many girls don't understand that female sterilization is an irreversible procedure and that they will never be able to have children again afterwards. Some of the interviewees weren't even fully aware that this intervention was invasive and involved surgery. 
A study commissioned by ACIDI [17] with view to the implementation of new policies of intervention in reproductive health for immigrant women, indicates that these women tend to have a high number of pregnancies due to abstaining from the use of contraceptive methods and having a poor understanding of the different existing methods. In this study, it is stated that in many cases, the generic promotion of alternative methods has been suggested as a way to get around the limitations deriving from lack of education, deep ignorance of the contraceptive methods, social constraints, as well as conflicting cultural beliefs and values regarding fertility and sexuality: the study reports cases of tubectomy prescription. My interviews reveal that the most publicized campaign was one that made the subcutaneous contraceptive implant (Implanon) freely available for all the women in the fertile age, a method that prevents pregnancies form occurring within a period of up to 3 years, and which is not so hard to use as the pill ("which these women either forget to take or take incorrectly") nor entail the difficulty of negotiating the use of condoms with partners.

Hormonal implants are presented by health professionals as one of the most practical and efficient pregnancy prevention methods. One of the health technicians involved in an intervention and information campaign on health and immigration, claimed that Implanon, being a new technology, would have an expensive market value, and therefore be of restricted access, especially to low income groups. Free distribution of the implant means overcoming "social barriers" and "cultural limitations" thus guaranteeing an infallible form of birth control. In agreement with this intervention's rationale of marking out its target audience, this informant adds, the women in greater need are those who are profiled as risk cases: women who are most prone to recurrent pregnancies due to social cultural and psychological factors; those who already have children of their own and are living on welfare; those who are more promiscuous and is hard to tell who got them pregnant; those who have unstructured families and are unable to provide proper care for the children they already have.

As Howard Becker already observed in 1963, it's interesting to note how important the gaze of the other is for the definition of the categories (vulnerable/in risk) and behaviours considered deviant. Thus, the process by which these women are classified as a risk group implies a categorization that is socially construed according to hegemonic moral values and the interests of those who have the power to attach that label. The category of risk group is itself interesting in this case, because it doesn't necessarily indicate a deviation from the norm, but only a possible deviation. In this context, Implanon is considered a preventive drug, indeed the most efficient and successful one, to reduce risks and prevent consequences (undesirable pregnancies due to age or family conditions) or deviation (fraud and the welfare queen). In the words of yet another technician, a psychologist in charge of training programmes:

The problem is that they are single-parent families. The children live with their mother only; it's extremely rare to find a father in these families. The difference is in how the concept of single-parent family is viewed:

"Among the African community it is not seen as a problem and they go on doing it, between successive pregnancies and subsidies, child support and GMI. The problem is that it's us who pay the taxes on which they raise all those children ...I pay for my daughter's school...their children don't even pay for their food, or books, or anything. So these people don't work, they have four or five children and may even go out and get that plasma TV set which I can't even afford to get for myself".

To solve the problem of welfare dependency or suspicion of fraud by mothers who- according to the interviewed social assistants - prefer to have more children in order to benefit from more child support-Implanon is presented as the most efficient and up to date in terms of prevention. The image of modernity conveyed in the leaflets makes reference both to its easy use - "you no longer have to remember when to take it" - contraceptive efficiency - "there are no registered pregnancies"- and also the increased freedom that this technology brings to its users. Contraceptive implants become symbols of modernity and increased efficiency as a solution for the problem of contraception. Hence, Implanon establishes a symbolical connection between its main target market - in the words of interviewed technicians: "immigrant women lacking the discipline to use the pill" - and the most advanced contraceptive technologies produced and consumed on a global scale. According to a large number of interviewed technicians, implants are an efficient weapon in the fight against teenage pregnancy, as well in helping to limit the surplus of children in families without conditions to provide adequate care for them. Implanon is indicated as the best solution to all the women in this population group who use the local health care services or $\mathrm{APF}^{7}$ Since the whole treatment is free, in order to amortize its cost (market value of $150 €$, plus $200 €$ for subcutaneous insertion and another $200 €$ in the event of future surgical extraction), implanted women sign a term of consent in which they agree not to remove the implant for a period of 3 years after insertion. Removal before this period entails reimbursement of the costs of the device as well as its insertion and removal, obviously limiting the freedom of choice among women with lesser means.

\footnotetext{
${ }^{7}$ Portuguese Pharmacological Association.
} 
As an effect of the cost and difficulty of removing the implant, control over their own body is transferred into the hands of health technicians. The debate on the obligation to keep the implant for a 3- to 5-year period is extremely political, and there are even voices who speak of abuse, especially in cases when the implant is indicated as the only contraceptive possibility, when removal is made exceedingly hard, or when it is implicitly suggested as a condition sine qua non to receive family support. Even though we cannot speak of coercive sterilization, promising money to feed, dress and shelter their families to low income women, even if at the cost of reproductive rights, might be seen as an offer hard to refuse. As such, long-term contraception as well as sterilization are advanced as a "cure" for poverty, an instrument of female empowerment, giving women the chance to become better mothers, to use their time more efficiently, to finding a job, and thus avoid falling prey to the moral vice of dependency.

Given that most immigrant women are quite reluctant to the idea of family planning, this kind of intervention based on birth control, apparently emerges as a good strategy to fight the variety of subsequent risks. Among them, High Commissioner for Health Maria do Céu Machado expresses her concerns regarding the problem of prematurity and low birth weight infants born form women of African origin due to social and even genetic reasons. This problem apparently contributes to project a negative image of the country internationally. ${ }^{8}$ According to a nurse involved in a project directed at maternal-infant health in suburban areas, the incentive to use subcutaneous implants also serves to prevent current tendencies among immigrant communities to use pregnancy interruption as a birth control method. Still in the words of Maria do Céu Machado:

"The illicit use of abortive drugs, which are easily obtained in the black market, and especially easy to buy among African and Brazilian communities, is one of the causes of premature births and babies born with health problems. Especially if we bear in mind that unsupervised pregnancies are frequent among women in these groups, to the point where many ignore when they became pregnant". 9

One of the main conclusions of the study Iguais ou Diferentes? Cuidados de Saúde materno infantil a uma população de imigrnates ${ }^{10}$ [29], is that immigrant communities register higher rates of foetal and neonatal immortality, illness during pregnancy, namely infectious diseases. Immigrants' vulnerability derives firstly from family conditions: unemployment, areas of work, education, single-parent

\footnotetext{
${ }^{8}$ Source: Público, 30.07 .2010

${ }^{9}$ Source: Público 2004.09.10

${ }^{10}$ Equal or diferent? Maternal-infant health care for immigrant populations.
}

or extended families, psychosocial and economic frailty, lack of domestic and personal hygiene and greater alcohol consumption [30]. In public health interventions of this kind, the notion of hygiene, with its connotations of civilization, education, responsibility and morality becomes a way to determine the suitability of immigrants to apply for citizenship. Illness, as well as teenage pregnancy, is considered a consequence of irresponsibility and a negative result of reckless and unrestrained conducts.

\section{For the Benefit of others. Health Promotion at Work}

With the aim of contributing in the most useful manner both to the public and theoretical debates, maintaining an unbiased approach has been this study's underlying principle, creating the conditions to understand both sides of the argumentsocial intervention technicians and users alike. In order to carry out our analysis of the social intervention programmes directed at immigrants in the Greater Lisbon area, I decided to study the recent changes in solidarity and social inclusion policies in the Portuguese case, using the concept of governability as a theoretical tool. I therefore tried to collect direct documental sources, namely institutional documents from the intervening parties in this political process in question, as well as carrying out interviews with privileged informants, both users and employees of those same services. The social assistance sector is conceived to advance collective well-being through the promotion of ethical conduct, wholesome habits and social responsibility, interfering in the life of communities that are considered "vulnerable".

The interpretation my approach makes of vulnerability is to consider it not as an external condition, but as the result of a specific "governmental rationale" by which groups or individuals are identified as vulnerable and consequently monitored, assisted and disciplined. Hence, the logic of vulnerability is a governmental one: it is a way of interpreting present contexts and projecting the future, justifying certain forms of intervention - social assistance for instance - in the present. As the recorded interviews demonstrate, the inherent rationale of the social assistance sector interprets the world as being divided between the strong and the weak, successful and marginalized and competent and incapable, and intends to raise the latter's empowerment substantially. A significant aspect of this rationale is the division of the population into groups that contribute (Homo sapiens, prudent-better) and groups that slow down (Homo ancestralis, reckless-inferior) the population's general well-being. The classification of individuals or groups as being in risk or dangerous makes it possible to prevent, contain or eliminate the threats that they pose. Furthermore, this type of classification is closely linked to the production and naturalization of racial, gender and class division between the prudent and imprudent, self- 
sufficient and dependent, citizen and alien and ethical and unethical.

In most of the analyzed documents, for instance, every time the term "vulnerability" is used, it is accompanied by the sentence "such as children, women, immigrants or mentally disabled" who are "disadvantaged from an economic, social or educational point of view". The expression "such as" is suggestive of some form of proximity or identification among the listed categories. This group of overlapping categories has already been noticed and criticized by several anthropologists, who have analyzed the Euro-American rhetoric on those who are culturally defined in the West as weak - to wit, women, children, mental patients, black people, the poor and the "tribal", as opposed to the "modern". Within this context, some of these groups could be considered vulnerable because they are unable to be responsible for their choices (for example children and people with mentally disabilities), or because they are intrinsically fragile and weak, and therefore need protection and supervision.

The identification of certain subcategories, such as gender, race, ethnic group or even class, helps to shape the areas of intervention that specifically target the limitations of individuals who fit into these particular identities. This is achieved, for example, through the creation of family planning counselling centres, support centres for women, parenting improvement workshops, specialized services for ethnic-cultural and immigrant groups and so forth. Such institutions are based on paternalistic notions, which reject the possibility that those social groups are capable of organizing themselves, or even that their interests may be diametrically opposed to those of the government. In addition, by labelling and classifying specific groups, these government programmes are actually creating social identities based on suppositions of weakness, victimization and impotence. Consequently, vulnerability is a kind of poverty, since the term describes an existing situation, of privation, lack of internal defences, lack of support, education, or any type of resources and opportunities.

Vulnerable people are by definition poor, insofar as they lack the material and cultural instruments to fend for themselves. According to this definition, vulnerable people are unable to exercise independent citizenship. The capacity for self-sufficiency and self-discipline is strengthened in the course of a person's lifetime, and some individuals don't acquire or fully develop this aptitude, either due to age, sex, culture, illness or any other restricting circumstances. Respect for the immature, the passive and the disabled demands providing protection for them. These persons therefore require "additional guarantees" and significant ethical guidance in the protection of their rights and well-being. The rationale of vulnerability thus justifies social interventions, insofar as the identification of any social problem demands some form of collective response. Consequently, those segments of the population identified as vulnerable are targeted for increased social policies aimed to provide support, education and "empowerment", interfering in the lives of populations considered "vulnerable" for their own good.

The idea of benevolent and humanitarian interference for the good of these populations, in the name of women's empowerment, better parenting and more responsible citizenship, justifies making decisions and imposing certain changes, even acting in ways that can be interpreted as illiberal. No one is acting against women, but on the contrary to free them and give them the chance for a better life. These policies are driven by the best intentions; their goal is to provide support, education and empowerment. In other words, these policies endeavour to alleviate the social suffering of the underprivileged in the name of moral virtue and compassion, but nevertheless avoid looking at the deeper causes of social exclusion, thus contributing to create an image of individuals lacking their own means, corresponding to the concept defined by Nguyen (2008) of "humanitarian citizenship". That is, the constitution of individuals bearing rights and responsibilities on the basis of specific social vulnerabilities. Moral feelings - or the aforesaid good intentions considered justified in themselves against any criticism - form the basis of today's public policies: nurturing its discourse and legitimating its practice, namely when they are intended for the oppressed, the subjugated and the excluded.

The vocabulary of suffering, victimization, as well as compassion and humanitarianism are thus part of contemporary political life. George Bush's 2002 intervention in which he defined the effort against poverty as a work of compassion, or Sarkozy's 2006 speech addressing to "the France that suffers" are two good examples of this attitude: a language whose ability to impose itself and create consensus is so strong as to justify the legitimacy of any kind of intervention or political decision. As Didier Fassin [18] so aptly points out, an analysis of the politics of compassion means approaching an extremely complex issue, in which solidarity and inequity form the basis of a profoundly asymmetrical relationship. And this asymmetry is political rather than psychological: paraphrasing Fassin, it is not so much a matter of criticizing compassion for its superior stance, but because it presupposes a relationship based on social difference. Compassion is directed from the top down, those who detain power (or knowledge) versus the vulnerable, the ignorant and the weak. Due to its moral premises, the humanitarian government over precarious lives creates a general consensus that disarms the critics: compassion makes no enemies.

The kind of study presented here requires revealing the intrinsic contradictions of political programs and discoursesbut that does not imply finding theories of conspiracy or social control in them. It means analyzing the organic construction of social aid projects and the grounds on which they are basednot doubting its good intentions. It means studying the explanations and attitudes of professionals working in the social 
sector at a given historic and political juncture-which is not the same as condemning forms of incompetence or bad faith. As a conclusion, but also as a disclaimer, I might say that this theme is as fascinating in its historical configuration and evolution as it is sensitive in its political implications-even more so at a time of economic crisis such as ours. The issues raised by assistentialism, social security, distribution of income or humanitarianism are fiercely fought over by the different political factions and parties; claimed by left and right wing governments for different reasons, and once again, as a substitute for other essential debates. While some become committed to deconstructing the "arrogance" and "colonialism" of political programs, others strive to defend the nobleness of social assistants, medical professionals and volunteers in the face of adverse conditions; still, others seek to see in the failings of the social assistance system reason enough to push for the sector's privatization and for cuts in fiscal benefits. A research of this kind can and should distance itself from the discussion of the strictly political conditions of the welfare state. Conversely, it can and must promote an approach that operates a double departure: one that implies not assuming the classifications of vulnerability and risk as givens, but instead dedicates itself to an analysis of the historical bases for that Will to Care, the immanent moral power of doing good; and another that seeks to investigate the deep paradigmatic shifts in the way distinctions among human beings are made, and the increasingly widespread and ingrained methods of governing all the dimensions of these people's lives.

Ethical Standard Statements All procedures followed were in accordance with the ethical standards of the responsible committee on human experimentation (institutional and national) and with the Helsinki Declaration of 1975, as revised in 2000 (5). Informed consent was obtained from all patients for being included in the study. Informed consent was obtained from all patients for which identifying information is included in this article. No animal studies were carried out by the author for this article.

Conflict of Interest Chiara Pussetti declares that she has no conflict of interest and she has not a financial relationship with the organization that sponsored the research.

\section{References}

1. Ahlberg BM. Is there a distinct African sexuality? A critical response to Caldwell. Africa: Journal of the International African Institute. 1994;64(2):220-42.

2. Andrews DL. The fact (s) of Michael Jordan's blackness: an excavation in four parts. Sociology of Sports Journal. 1996;13(2):125-58.

3. Bittman M, Pixley J. The double life of the family. Sydney: Allen \& Unwin Eds; 1997.

4. Borrero $\mathrm{S}$ et al. Race, insurance status, and tubal sterilization. Obstet Gynecol. 2007;109(1):94-100.

5. Caldwell J. The impact of the African AIDS epidemic. Health Transit Rev. 1997;7 Suppl 2:169-88.
6. Caldwell J. Rethinking the African AIDS epidemic. Popul Dev Rev. 2000;26(1):117-35.

7. Caldwell J, Caldwell P. Fertility control as innovation: a report on indepth interviews in Ibadan, Nigeria, in van de Walle and Ebigbola, 1987, The cultural roots of African fertility regimes. Proceedings of a Conference. Philadelphia: Population Studies Center; 1987. p. 223-51.

8. Caldwell J, Caldwell P. The cultural context of high fertility in subSaharan Africa. Popul Dev Rev. 1987;13(3):409-37.

9. Caldwell J, Caldwell P. Africa: the new family planning frontier. Stud Fam Plan. 2002;33(1):76-86.

10. Caldwell J, Caldwell P, Quiggin P. The social context of AIDS in subSaharan Africa. Popul Dev Rev. 1989;15(2):185-234.

11. Caldwell J, Caldwell P, Quiggin P. The African sexual system: reply to Le Blanc et al. Popul Dev Rev. 1991;17(3):506-15.

12. Challinor EP. (Ir)responsible mothers? Cape Verdeans and Portuguese social care. International Journal of Migration, Health and Social Care. 2012;8(1):12-21.

13. Cole D. No equal justice: race and class in the American criminal justice system. New York: New Press; 2000.

14. Cole J, Thomas LM. Love in Africa. Chicago: University Chicago Press; 2009.

15. Collins PH. Black sexual politics: African Americans, gender, and the new racism. New York: Routledge; 2004.

16. Cowen M, Shenton R. Doctrines of development. London and New York: Routledge; 1996.

17. Dias S., Famer Rocha C. E Horta R. 2009. Saúde sexual e reprodutiva de mulheres imigrantes africanas e brasileiras, ACIDI, OI 32.

18. Fassin D. La raison humanitaire. Une histoire morale du temps présent. Gallimard: Hautes Etudes; 2010.

19. Feagin J. Racist America: roots, current realities and future reparations. New York: Routledge; 2001.

20. Fields J. 'Children having children': race, innocence and sexuality education. Soc Probl. 2005;52:549-79.

21. Foucault M. Discipline and punish: the birth of the prison. NewYork: Vintage; 1995.

22. Gilman S. Differences and pathology: stereotypes of sexuality, race and madness. Ithaca, NY: Cornell University Press; 1985.

23. Gray H. Watching race: television and the struggle for Blackness. Minneapolis: University of Minnesota Press; 1995.

24. Grossberg L. We gotta get out of this place: popular conservatism and postmodern culture. New York: Routledge; 1988.

25. Heald S. The power of sex: reflections on the Caldwell's 'African Sexuality' thesis. in Heald S. manhood and morality: sex, violence and ritual in Gisu society. New York: Routledge; 1995.

26. Hooks B. Black looks: race and representation. Boston: South End; 1992.

27. Kendall N. Sexuality education in an abstinence-only era: a comparative case study of two US states. Sex Res Soc Policy. 2008;5:23-44.

28. Leonard DJ. The next M.J. or the next O.J.? Kobe Bryant, race, and the absurdity of colorblind rhetoric. Journal of Sport \& Social Issues. 2004;28:284-313.

29. Machado M. Iguais ou diferentes? Cuidados de saúde materno-infantil a uma população de imigrantes. Porto: Editor Laboratórios Bial; 2007.

30. Machado M. et al. 2007b. Cuidados de saúde materna e infantil a uma população de imigrantes, in Dias, Sónia (org.), Revista Migrações Número Temático Imigração e Saúde, Setembro 2007, n. ${ }^{\circ}$, Lisboa: ACIDI, pp. 103-127.

31. Mehta US. Liberalism and empire. Chicago: University of Chicago Press; 1999.

32. Pussetti C. A patologização da diversidade. Uma reflexão antropológica sobre a noção de culture-bound syndrome (Pathologizing diversity. An anthropological criticism to the concept of culturenbound syndrome), Etnografica, vol. X(1). Lisbon: CEAS; 2006. p. 5.

33. Pussetti C, editor. Migrantes e Saúde Mental: a construção da competência cultural, Estudo 33 da Colecção de Estudos do Observatório da Imigração, OI. Lisboa: ACIDI; 2009. 
34. Pussetti C. Biopolíticas da depressão nos imigrantes Africanos, Saúde e sociedade 18 (4). São Paulo: Oct-Dec; 2009. p. 590-608.

35. Pussetti C. Amor, emoción y relaciones de género en un contexto en transformación (Archipiélago de las Bijagós; Guinea-Bissau. In: Gomez S, editor. Culturas sexuales indígenas. México y otras realidades II. Santiago de Compostela, Espanha: Andavira Editora; 2011. ISBN 9788484085928.

36. Pussetti C., Barros V. 2012. «Ethnopolitics of risk and vulnerability», Coordination of the Special Issue, International Journal of Migration, Health and Social Care, VOL. 8 NO. 1 2012, ISSN: 1747-9894.

37. Pussetti C, (T-SHaRE European team: CRIA, ASL NA2 Nord, Centro Franz Fanon, Centre Minkowska, Kulturno Drustvo Gmajna; Nakmi; Folkeuniversitetet; Aracne; Centro Shen), TSHaRE transcultural standards and guidelines for practice and training. Lisbon: CRIA; 2012. ISBN 9788890724527.
38. Pussetti C. et al. (T-SHaRE European team: CRIA, ASL NA2 Nord, Centro Franz Fanon, Centre Minkowska, Kulturno Drustvo Gmajna; Nakmi; Folkeuniversitetet; Aracne; Centro Shen) 2012b. A comparison of health service accessibility for immigrants among European countries in the T-Share project, Porta Di Massa|Laboratorio Autogestito Di Filosofia Epistemologia E Scienze Politico-Sociali (Issn 1973-2619), TShare Special Issue, pp. 15-20.

39. Rose S. Going too far? Sex, sin and social policy. Social forces. In: Feagin JR, editor. Racist America: roots, current realities and future reparations, vol. 84. Routledge: New York; 2005. p. 1207-32.

40. Stacey J. In the name of the family: rethinking family values in the postmodern age. Boston: Beacon; 1996.

41. West C. Race matters. Boston: Vintage; 1993. 